\title{
Studies on Mechanistic Role of Natural Bioactive Compounds in the Management of Obesity An Overview
}

\author{
Natalia E. G. Alves ${ }^{1}$, Samanta T. Valdés ${ }^{1}$, Carlos M M.Silveira ${ }^{1}$, Hércia S. D. Duarte Martino ${ }^{1}$, \\ Fermin I. Milagro $^{2}$, María J. Moreno-Aliaga ${ }^{2}$ and Sônia M. R. Ribeiro ${ }^{1 *}$ \\ ${ }^{I}$ Department of Nutrition and Health, University Federal of Viçosa, 36570-000, Viçosa, MG, Brazil \\ ${ }^{2}$ Department of Nutrition, Food Sciences, Physiology and Toxicology, University of Navarra, 31008, Pamplona, Spain
}

\begin{abstract}
Obesity is recognised as a condition of low-grade chronic inflammation resulting from macrophage infiltration of adipose tissue and activation of inflammatory pathways by oxidative stress mechanisms that lead to the development of insulin resistance. Various natural bioactive compounds (NBCs) with anti-inflammatory and anti-oxidant effects may improve adipocyte dysfunction associated with metabolic syndrome. The present review focuses on the effects of phenolic compounds, n-3 long-chain polyunsaturated fatty acids (n-3 LC-PUFA) and lipoic acid (LA) on the pathophysiological mechanisms of obesity. In this review, a total of 120 studies were included, and data thus obtained reflect beneficial physiological effects of n-3 LC-PUFA, LA and different phenolic compounds, including kaempferol, luteolin, apigenin, quercetin, resveratrol, curcumin, catechins, phenolic acids, in the prevention and/or attenuation of metabolic disturbances associated with obesity. Additionally, information from clinical studies provides new insights for defining the doseresponse relationship of dietary compounds, necessary time of exposure and potential side effects of these NBCs in the treatment of obesity and indicates further study is needed to verify these relationships.
\end{abstract}

Keywords: Insulin resistance, Lipoic acid, Metabolic disturbances, n-3 Long-chain polyunsaturated fatty acids, Obesity treatment, Phenolic compounds.

\section{INTRODUCTION}

Obesity is considered a major public health problem worldwide and its prevalence continues to rise uncontrollably [1]. In clinical practice, it is quite obvious that metabolic alterations in obese individuals limit the likelihood of positive response to treatment while favouring the evolution of the metabolic syndrome as well as the development of comorbidities such as diabetes and vascular complications [2]. Primary strategies for the treatment of obesity are reduction of dietary energy intake and increase of physical energy expenditure, and lifestyle changes are important for long-term success. However, a large percentage of patients to whom such treatment is recommended regain most of the weight lost during the treatment in subsequent months or years, and it is common for them to resort to expensive surgery, an invasive procedure, in an effort to achieve long-term weight loss. Thus, healthcare practitioners and the general public continue to seek more effective strategies for obesity prevention and management [3].

There is a great interest in finding adjuvant therapy for the treatment of obesity to correct or mitigate metabolic

\footnotetext{
*Address correspondence to this author at the Department of Nutrition and Health, University Federal of Viçosa, 36570-000, Viçosa, MG, Brazil;

Tel: 55-31-3899-2569; Fax: 55-31-3899-2541;

E-mail: nat.pedro@yahoo.com.br
}

changes that increase inflammation, oxidative stress and the occurrence of comorbidities, particularly insulin resistance. Attenuation of inflammation and oxidative stress, and increased fatty acids oxidation in the adipose tissue are important points to improve the metabolism, reducing the risk of comorbidities [4-9]. Fig. (1), shows a representative scheme of the mechanisms related to oxidative stress and inflammation in obesity.

Natural bioactive compounds (NBCs) are substances contained in foods that provide a verifiable benefit to human health. Evidence has been shown that different NBCs modulate inflammatory genes by acting through various signalling pathways [10]. Moreover, some NBCs have the potential to improve adipocyte dysfunction associated with metabolic syndrome [11] as well as favour fatty acid oxidation and reduce lipogenesis [12]. The modulation of signalling pathways by anti-oxidant NBCs results in increased defence of several tissues against electrophilic stressors and oxidative insults; intervention in these pathways is therefore a strategy for the prevention and treatment of metabolic diseases associated with oxidative stress [13].

The aim of the present study is to review recent findings concerning the effects of three types of NBCs (phenolic compounds, n-3 LC-PUFA and lipoic acid) on obesity, including their mechanisms of action on adipocytes and on systemic levels. 


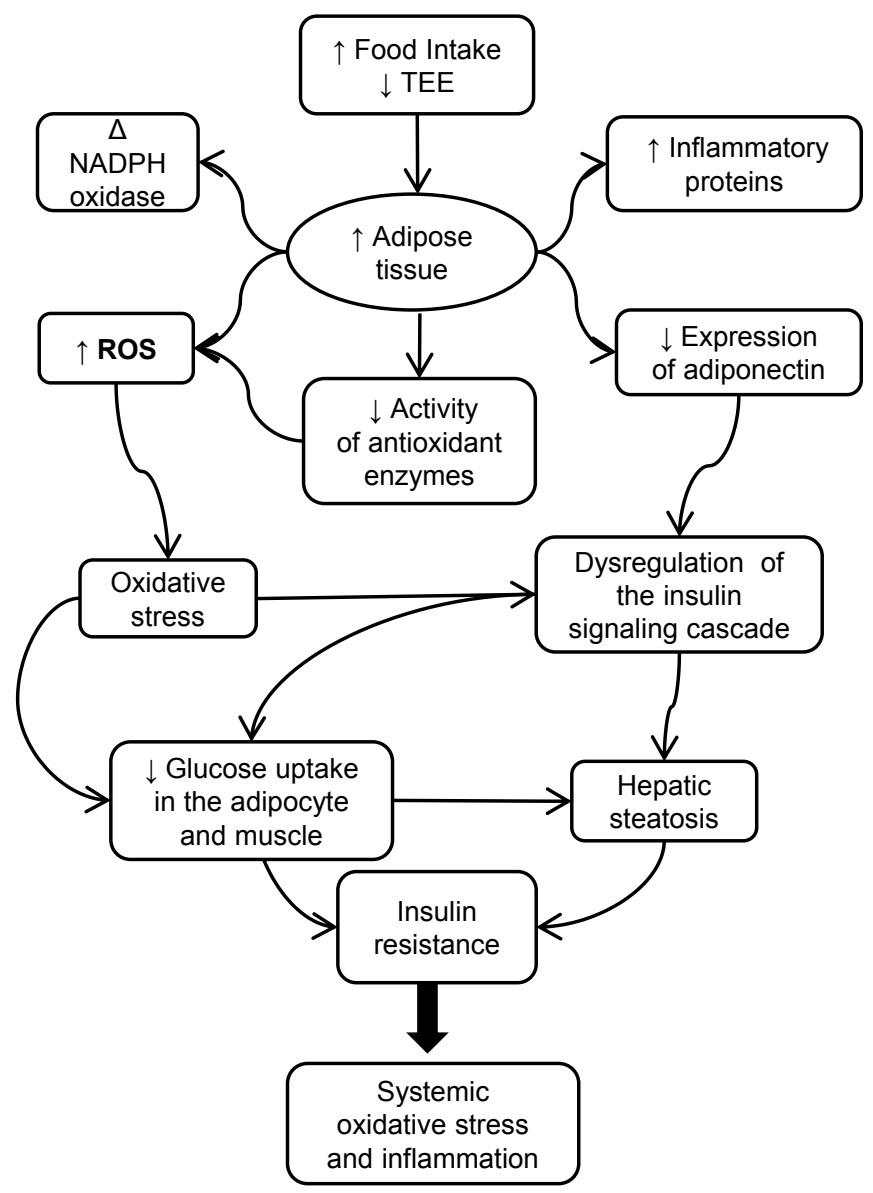

Fig. (1). Mechanisms related to oxidative stress and inflammation in obesity. $\uparrow$, increase; $\downarrow$, reduction; $\Delta$, activation; TEE, total energy expenditure; ROS, reactive oxygen species; NADPH-oxidase, nicotinamide adenine dinucleotide phosphate-oxidase.

\section{PHENOLIC COMPOUNDS}

Polyphenols (including flavonoids and resveratrol) and phenolic acids have demonstrated anti-inflammatory and anti-adipogenic activities in several types of animal and human cells, both in in vitro (Table 1) and in vivo models (Table 2).

\section{Kaempferol, Luteolin and Apigenin}

Kaempferol, luteolin and apigenin (Fig. 2 a, b, c) are flavonoids that have attracted great attention due to their ability to reduce the risks of chronic diseases through antiinflammatory activity [14] and to alter the immune function by inhibiting enzymes that are activated in inflammatory conditions. Inactivated enzymes include the family of mitogen-activated protein kinases (MAPK - ERK, JNK and P38) that belong to the TNF- $\alpha$ signalling pathway, which activates nuclear factor kappa B (NF- $\mathrm{B})$ [15].

In vitro studies, described in Table $\mathbf{1}$, have demonstrated the anti-inflammatory effects of kaempferol, luteolin and apigenin in different cell types. Macrophages, endothelial cells and 3T3-L1 adipocytes treated with kaempferol, luteolin and apigenin have shown reduced inflammatory responses. Moreover, kaempferol and luteolin induce the activation of PPAR- $\gamma$ and its target genes (such as leptin, GLUT4 and adiponectin) as well as enhance insulin sensitivity in adipocytes [16-21]. Apigenin-induced activation of AMP-activated protein kinase (AMPK) that reduced the expression of adipogenic genes, thus suppressing adipogenesis in 3T3-L1 cells [22].

Kaempferol, apigenin and luteolin have the ability to block molecular mechanisms involved in triggering the inflammatory response, especially the signalling pathway of the transcription factor NF- $\kappa B$, which increases the expression of genes that encode proteins involved in obesity-related inflammation. Modulation of the cyclo-oxygenase (COX) pathway by inhibition of nitric oxide production seems to be the main anti-inflammatory mechanism of action exhibited by flavonoids [23].

Benefits beyond those described above have been observed for apigenin and kaempferol. In animal studies (Table 2), apigenin reduced food intake of $\mathrm{C} 57 \mathrm{BL} / 6 \mathrm{~J}$ mice by increasing gene expression of anorexigenic neuropeptides [24]. The potential of kaempferol to increase energy expenditure should not be dismissed because this flavonoid may contribute to an increase in skeletal myocyte oxygen consumption of up to $30 \%$, can affect regulation of metabolically important genes and activate thyroid hormones [25]. 
Table 1. In Vitro Studies Showing Effects of Phenolic Compounds in the Modulation of Inflammatory Pathways and Adipogenesis

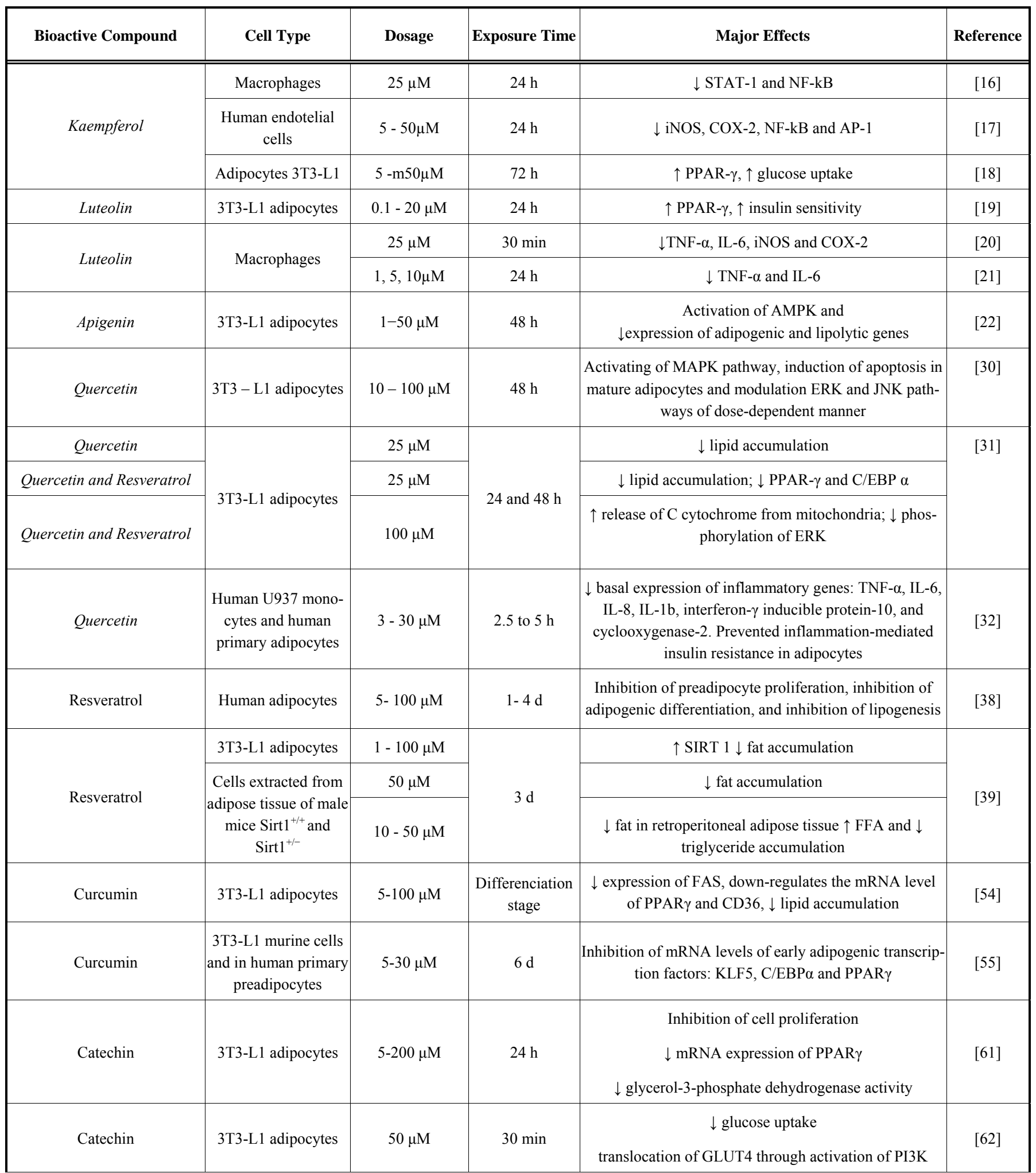

$\downarrow$, decrease; $\uparrow$, increase; STAT-1, signal transducers and activators of transcription; NF-kB, nuclear factor kappa B; iNOS, inducible nitric oxide synthase; COX-2, ciclooxigenase-2; AP-1, activator protein 1 ; PPAR- $\gamma$, peroxisome proliferator-activated receptors- $\gamma$; TNF- $\alpha$, tumour necrosis factor- $\alpha$; IL, interleukin; AMPk, AMP-activated protein kinase; MAPK, mitogen-activated protein kinase; ERK, extracellular signal-regulated kinases; JNK, c-Jun N-terminal protein kinases; $\mathrm{C} / \mathrm{EBP} \alpha, \mathrm{CCAAT} / \mathrm{enhancer}$ binding protein; SIRT1, sirtuin-1; FFA, free fatty acid. 
Table 1. Contd.....

\begin{tabular}{|c|c|c|c|c|c|}
\hline Bioactive Compound & Cell Type & Dosage & $\begin{array}{c}\text { Exposure } \\
\text { Time }\end{array}$ & Major Effects \\
\hline \hline Catechin & 3T3-L1 adipocytes & $0.1-10.0 \mu \mathrm{M}$ & $\begin{array}{c}\text { Growth and } \\
\text { differenciation } \\
\text { phase }\end{array}$ & $\begin{array}{c}\downarrow \text { preadipocyte proliferation with dose dependent effect, } \\
\downarrow \text { expression of C/EBP } \alpha \text { and PPAR } \gamma \\
{[63]}\end{array}$ \\
\hline $\begin{array}{c}\text { Clorogenic, o-cumaric and } \\
p \text {-cumaric acids }\end{array}$ & $\begin{array}{c}3 \mathrm{~T} 3 \text {-L1 pre- } \\
\text { adipocytes }\end{array}$ & $100 \mu \mathrm{M}$ & $72 \mathrm{~h}$ & Cell cycle arrest in G1 phase \\
\hline $\begin{array}{c}\text { Galic acid } \\
\text { [73] } 3 \text { - L1 adipo- } \\
\text { cytes }\end{array}$ & $250 \mu \mathrm{M}$ & $72 \mathrm{~h}$ & $\begin{array}{c}\text { Induction of apoptosis through the Fas and mitochon- } \\
\text { drial pathway; } \downarrow \text { glycerol-3-phosphate dehydrogenase } \\
\text { activity }\end{array}$ \\
\hline $\begin{array}{c}\gamma \text {-orizanol acid } \\
\text { Macrophages }\end{array}$ & $1 \mathrm{mM}$ & $22 \mathrm{~h}$ & $\begin{array}{c}\text { Supression of NF-kB activation, } \downarrow \text { inflammatory } \\
\text { response }\end{array}$ \\
\hline $\begin{array}{c}\text { Hydroxycinnamic acid de- } \\
\text { rivatives }\end{array}$ & $\begin{array}{c}3 \mathrm{~T} 3-\mathrm{L} 1 \text { adipo- } \\
\text { cytes }\end{array}$ & $1 \mu \mathrm{M}$ & $72 \mathrm{~h}$ & $\begin{array}{c}\text { Regulation of adiponectin secretion through inhibition } \\
\text { of NF-kB activation }\end{array}$ \\
\hline
\end{tabular}

$\downarrow$, decrease; $\uparrow$, increase; FAS, fatty acid synthase; CD36, scavenger receptor of macrophage; KLF5, Krüppel-like factor; C/EBP $\alpha$, CCAAT/enhancer binding protein; PPAR- $\gamma$, peroxisome proliferator-activated receptors- $\gamma$; GLUT4, glucose transporter type-4; PI3K, Phosphoinositide 3-kinase ; NF-kB, nuclear factor kappa B.

Table 2. In Vivo and Ex Vivo Studies on the Effects of Phenolic Compounds in the Modulation of Inflammatory Pathways and Adipogenesis

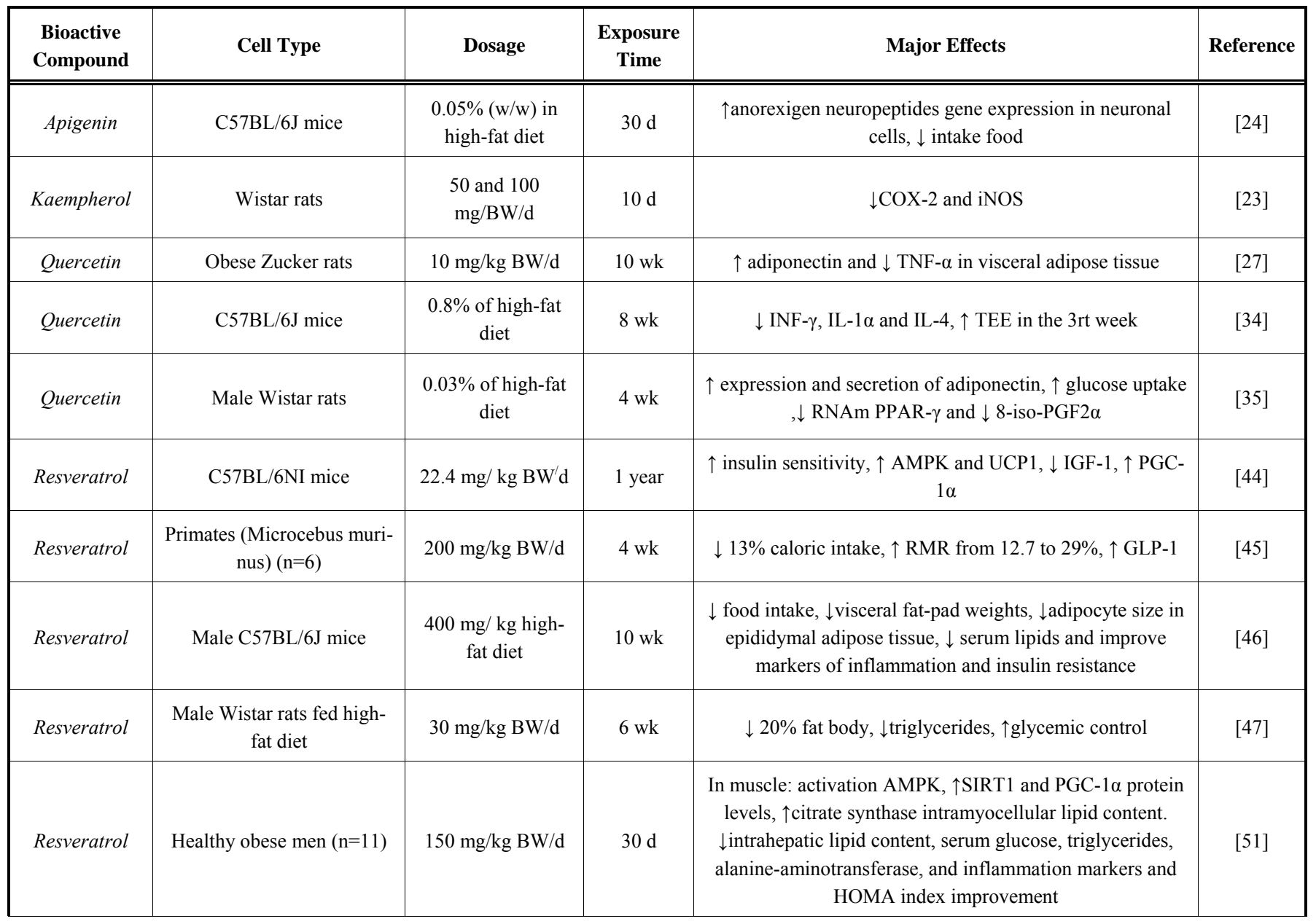


Table 2. Contd.....

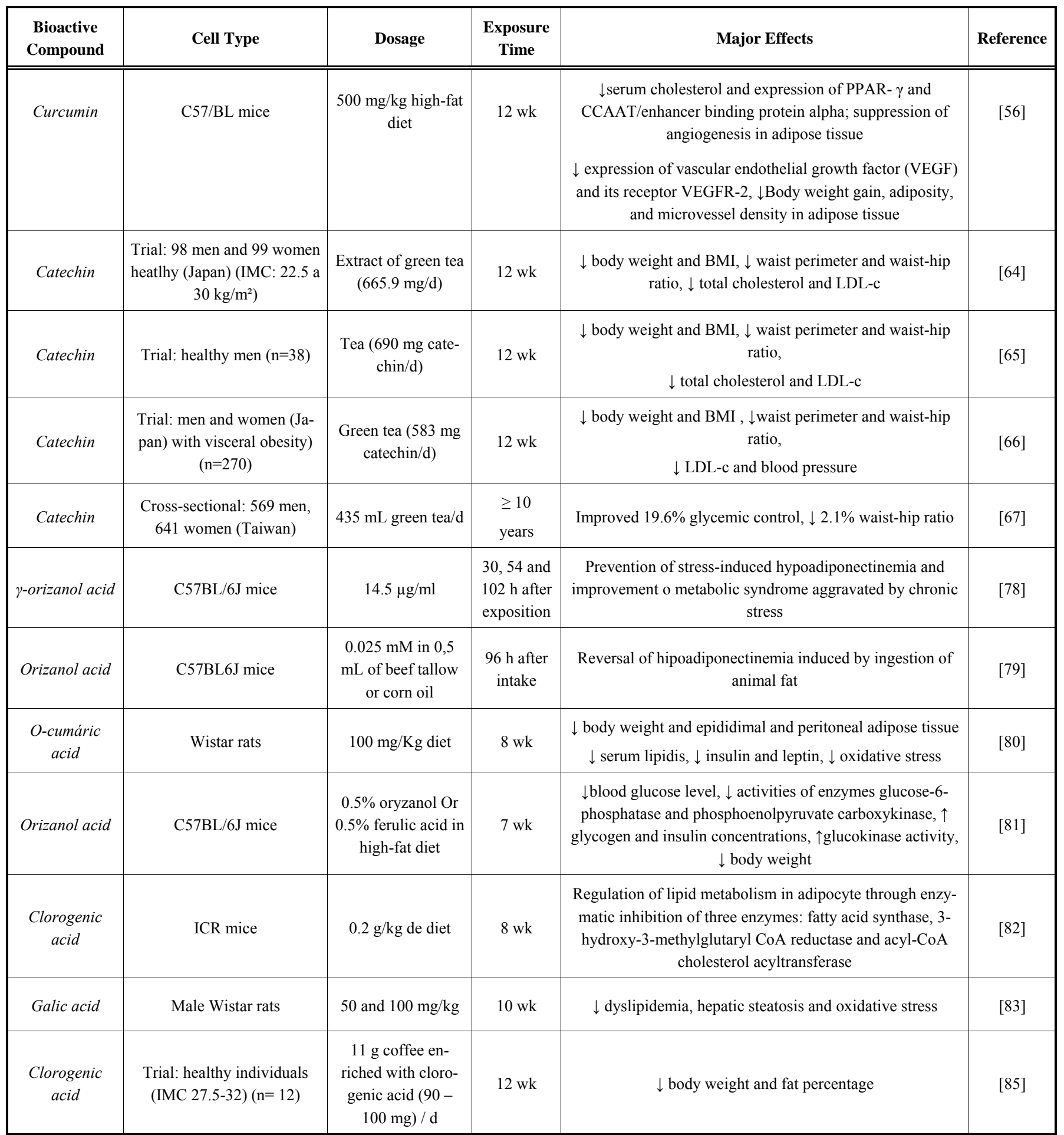

$\downarrow$, decrease; $\uparrow$, increase; COX-2, ciclo-oxygenase 2; iNOS, inducible nitric oxide synthase; TNF- $\alpha$, tumor necrosis factor- $\alpha$; INF- $\gamma$, interferon-gamma; IL, interleukin; TEE, total energy expenditure; PPAR- $\gamma$, peroxisome proliferator-activated receptors- $\gamma$; 8 -isso-PGF2 $\alpha$, prostaglandin2;AMPK, AMP-activated protein kinase; UCP1, mitochondrial uncoupling proteins; IGF-1, insulin-like growth factor 1; PGC-1 $\alpha$, peroxisome proliferator-activated receptor-gamma coactivator 1 alpha; RMR, resting metabolic rate; Sirt1, sirtuin-1; GLP-1, glucagon-like peptide-1; SIRT1, sirtuin-1; HOMA, homeostasis model assessment; VEGF, vascular endothelial growth factor; VEGFR-2, vascular endothelial growth factor receptor 2

$\downarrow$, decrease; $\uparrow$, increase; BMI, body mass index, LDL-c, low-density-lipoprotein cholesterol

It is noteworthy that most studies on these compounds have been performed In vitro with the aim to clarify mechanisms of action; they have been focused on elucidating implications for inflammation. Human intervention studies are needed to confirm the health benefits and to establish the dose-response relationship for kaempferol, apigenin and luteolin in obesity treatment. 
<smiles>O=c1c(Br)c(-c2ccc(Br)c(P)c2)oc2cc(O)cc(O)c12</smiles>

(a)- kaempferol: $\mathrm{R}_{1}=\mathrm{OH} ; \mathrm{R}_{2}=\mathrm{H} ; \mathrm{R}_{3}=\mathrm{OH}$ (b)- Luteolin: $\mathrm{R}_{1}=\mathrm{H} ; \mathrm{R}_{2}=\mathrm{OH} ; \mathrm{R}_{3}=\mathrm{OH}$ (c)- Apigenin: $\mathrm{R}_{1}=\mathrm{H} ; \mathrm{R}_{2}=\mathrm{H} ; \mathrm{R}_{3}=\mathrm{OH}$ (d)-Quercetin: $\mathrm{R}_{1}=\mathrm{OH} ; \mathrm{R}_{2}=\mathrm{OH} ; \mathrm{R}_{3}=\mathrm{OH}$

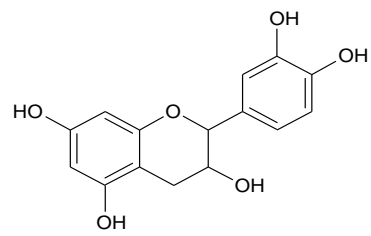

(g) - Catechins<smiles>Oc1ccc(/C=C/c2cc(O)cc(O)c2)cc1</smiles>

(e) - Resveratrol<smiles>COc1cc(/C=C/C(=O)CC(=O)/C=C/c2ccc(O)c(OC)c2)ccc1O</smiles>

(f) - Curcumin
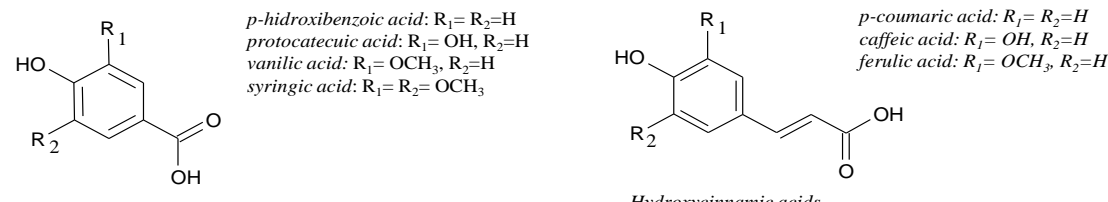

Hydroxycinnamic acids

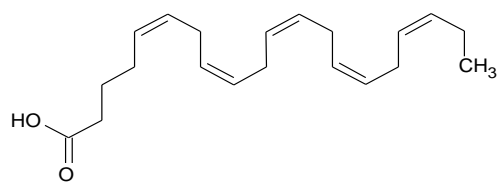

EPA (h)- Phenolic acids<smiles>CC/C=C\C/C=C\C/C=C\C/C=C\C/C=C\C/C=C\CCC(=O)O</smiles>

DHA

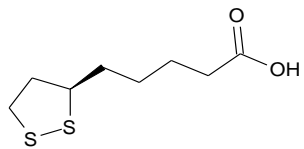

(j) - Lipoic acid

(i) -n-3 PUFA

Fig. (2). Chemical structures of bioactive compounds. EPA, eicosapentaenoic acid; DHA, docosahexaenoic acid.

\section{Quercetin}

Quercetin (Fig. 2d) is a flavonoid that has been noted for beneficial effects on human health associated with its antioxidant [26] and anti-inflammatory [27] properties. It may also modulate LDL-cholesterol levels [28] and blood pressure [29].

The anti-adipogenic effects of quercetin have been demonstrated in 3T3-L1 and human adipocytes, whereas its antiinflammatory effects have been revealed in macrophages (Table 1). The main anti-adipogenic mechanism is the induction of apoptosis through modulation of extra-cellular signalregulated kinase (ERK) and c-Jun N-terminal kinase (JNK) pathways [30]. When combined with resveratrol, quercetin has decreased lipid accumulation and inhibited PPAR- $\gamma$ and C/EBP transcription factors. Both bioactive compounds, combined at concentrations of $100 \mu \mathrm{M}$, resulted in increased release of cytochrome $\mathrm{C}$ from mitochondria to the cytosol and decreased ERK phosphorylation [31]. In human cells, quercetin prevented inflammation and insulin resistance in adipocytes exposed to macrophage-conditioned media [32]. Indeed, there is evidence that quercetin is at least as effective as resveratrol at attenuating TNF- $\alpha$-mediated inflammation and insulin resistance in primary human adipocytes [33].

The anti-inflammatory effects of quercetin in adipose tissue have been confirmed in animal studies, as shown in Table 2. Its effects include evident improvement in the degree of inflammation, increased plasma and mRNA levels of adiponectin, and decreased TNF- $\alpha$ production in visceral adipose tissue $[27,34,35]$. Thus, in mice fed a high fat diet $(45 \%)$, a supplementation with $0.8 \%$ quercetin had no effect on body weight or body composition, but induced a reduction in the levels of inflammatory markers (IFN- $\gamma$, IL-1 $\alpha$ and IL-4) [34].

Beneficial effects of quercetin on energy metabolism and glucose uptake have also been observed. A transient increase on energy expenditure was observed during the third week of quercetin supplementation in mice fed with high-fat diet followed by a reduction in circulating quercetin between weeks 3 and 8, suggesting a metabolic adaptation to the early effects of quercetin on energy expenditure [34].

In high-fat-fed Wistar rats, a supplementation containing $0.03 \%$ quercetin reduced fasting glucose levels, increased plasma and mRNA levels of adiponectin, decreased oxidative stress in plasma (measured as 8-iso-PGF2a), and decreased PPAR- $\gamma$ mRNA levels in adipose tissue [35]. These authors also observed that quercetin stimulated the secretion of adiponectin by mechanisms independent of PPAR- $\gamma$.

In summary, the anti-inflammatory, anti-oxidant and proapoptotic effects of quercetin may prove to be useful in the treatment of obesity. The first and the second mechanisms are currently considered the primary instigators of pathophysiological alterations related to the onset of metabolic syndrome. However, further human intervention studies are needed to confirm the efficacy of quercetin in reducing body fat and improving pathophysiological changes. In addition, it 
is necessary to establish recommendation for adequate dosage and exposure times.

\section{Resveratrol}

Resveratrol (Fig. 2e) is a phenolic compound that exhibits anti-inflammatory and cardioprotective effects that are partially attributed to its high anti-oxidant activity [36, 37]. Several in vitro and in vivo studies have demonstrated the effects of resveratrol in the regulation of adipogenic mechanisms and inflammatory processes.

The results of the in vitro studies, as shown in Table 1, indicate that resveratrol exerts the following beneficial effects on obesity management: a decrease in lipid synthesis in adipocytes by PPAR- $\gamma$ supression, an increase in lipolysis, and a reduction in lipid accumulation in maturing preadipocytes [38, 39], through the inhibition of lipogenesis and differentiation of 3T3-L1 adipocytes via activation of AMPK in a dose-dependent manner [40], and in the inhibition of adipogenesis by means of GSH up-regulation [41].

Through the mechanisms described above, resveratrol may decrease the expression and secretion of proinflammatory adipokines such as IL-6, TNF- $\alpha$ and PAI-1 [42], increase the expression and secretion of adiponectin [43], and improve mitochondrial oxidative function by increasing sirtuin activity [38], mitochondrial biogenesis and fatty acid oxidation [39].

The results of in vivo studies in rats (Table 2) have shown that resveratrol induces changes associated with longevity including increased insulin sensitivity, reduced levels of insulin-like growth factor (IGF-1), increased AMPK and quantity of mitochondria, increased activity of PGC- $1 \alpha$ and improved motor function of animals [44]. In primates, resveratrol reduced the body weight gain by increasing satiety and resting metabolic rate [45]. In mice fed with a high-fat diet, resveratrol decreased food intake and down-regulated adipogenic and inflammatory processes [46]. Intra-peritoneal administration of resveratrol in mice suppressed food intake by $20.0 \%$ and $17.2 \%$ for 24 and $48 \mathrm{~h}$, respectively. The inhibition of food intake was mediated by a down-regulation of neuropeptide $\mathrm{Y}$ and agouti-related protein, two neuropeptides involved in satiety [47].

Still, the ability of resveratrol to induce a reduction in food intake has not been universally observed $[45,46,48$, 49]. This difference could be attributed to the dose and period of supplementation. However, even in short-term studies, and before weight reduction, resveratrol improved the metabolic state inherent to obesity [50]. In overweight subjects, resveratrol also displayed several beneficial effects on muscle metabolism by reducing inflammatory markers and insulin resistance [51].

A consensus exists regarding the beneficial effects of resveratrol on adipogenesis mitigation. However, its benefits

on obesity treatment should be further studied, focusing special attention on the establishment of safe doses and the adequate intake of this compound to attenuate inflammation and metabolic alterations. Data suggest that the potential therapeutic application of resveratrol as an adjunct in the obesity treatment should be exploited because, in addition to direct effects on adipocytes, its supposed appetite-reducing effect is very attractive. In clinical practice, unregulated appetite is a major constraint to the maintenance of body weight in obese individuals.

\section{Curcumin}

Curcumin (Fig. 2f) is a polyphenol extracted from the rhizomes of turmeric (Curcuma longa L) [52]. It is known for its beneficial health effects attributed to anti-inflammatory, anti-oxidant and hypolipidemic properties [53].

Different in vitro assays (Table 1) have demonstrated that curcumin inhibits adipocyte differentiation $[54,55]$ and decreases lipid accumulation by reducing the expression of fatty acid synthase (FAS), as well as by down-regulating the PPAR- $\gamma$ and CD36 mRNA levels during adipocyte differentiation [54]. In C57/BL mice (Table 2), curcumin reduced body weight gain and adiposity, decreased serum cholesterol and caused suppression of angiogenesis in adipose tissue [56].

In addition to its direct action on the adipocyte, evidence has been shown that curcumin attenuates obesity-associated metabolic changes in the liver by blocking leptin signalling through reducing leptin receptor phosphorylation and inducing an increase in adiponectin secretion, which is important for improving obesity-associated inflammation [57]. These results provide novel insights into the therapeutic mechanisms of curcumin to improve hepatic metabolism and attenuate changes associated with non-alcoholic steatohepatitis [58]. These effects have great therapeutic value due to the common occurrence of hepatic dysfunction in the obese.

A recent review concluded that curcumin may interact with proteins in adipocytes, down-regulating inflammatory adipocytokines, resistin and leptin, and up-regulating adiponectin. The interactions of curcumin with several signal transduction pathways should reverse insulin resistance, hyperglycemia, hyperlipidemia, and other inflammatory symptoms associated with obesity and metabolic diseases [59]. Nevertheless, studies in humans are needed to explore the effects of curcumin in the treatment and control of metabolic abnormalities linked to obesity because knowledge at this level is still scarce.

\section{Catechins}

Catechins (Fig. 2g), such as (-)-epicatechin, 3-O-galloyl(-)-epicatechin, (-)-epigallocatechin and epigallocatechin 3gallate (GEGC), are polyphenols present in high concentrations in tea [60]. Green tea and catechins have been demonstrated in cell culture (Table 1), human trials and crosssectional studies (Table 2) that may reduce adipocyte differentiation and proliferation, lipogenesis [61-63], fat mass, body weight, oxidised LDL-c and blood pressure, and can improve glycemic control [64-67]. GEGC has been widely investigated for its possible body fat-reducing effects.

Evidences have shown that the anti-adipogenic effects of catechins are mediated by several mechanisms including the inhibition of cell proliferation, a decrease in PPAR- $\gamma$ and $\mathrm{C} / \mathrm{EBP}-\alpha$ expression, an increase in glucose uptake [61-63], 
and the induction of thermogenesis via sympathetic nervous system through inhibition of the enzyme catechol-Omethyltransferase as well as noradrenaline enhancement [68]. Moreover, reduced body fat accumulation may also be explained by a decrease in the digestibility of the diet [69, 70], higher faecal energy loss, increased post-prandial fat oxidation and a reduction in dietary lipid incorporation into adipose tissue, liver and skeletal muscle [70].

These results have suggested the promising therapeutic potential of catechins in obesity management. Recent studies emphasise many benefits of beverages rich in catechins, including the improvement of body composition and lower abdominal adiposity in moderately overweight subjects [71] and the attenuation of oxidative stress [72]. In diabetic subjects, catechin-rich beverages have also contributed to reducing body weight, increasing adiponectin secretion and recovering insulin-secretory ability [73].

Despite evidence of health benefits from bioactive compounds in tea, many doubts still remain regarding its potential in the treatment of obesity. The present review has verified that many different types of tea and different dose ranges reflecting varying levels of catechin ingestion were employed in studies to date. Moreover, the method of preparation and geographic origin of tea plants can influence catechin content and, therefore, the bioactivity of each tea and its extracts. All of these factors should be taken into account in the use of green tea as an adjunct in obesity management.

\section{Phenolic acids}

Phenolic acids (Fig. 2h) constitute a broad class of compounds that are divided into two main groups, hydroxycinnamic acids (caffeic, ferulic, coumaric and synaptic acids) and hydroxybenzoic acids (gallic, p-hydroxybenzoic, protocatechuic, vanillic and syringic acids) [60]. Among the biological activities of phenolic acids, their anti-oxidant and anti-inflammatory properties have attracted great attention. Additionally, adipose tissue is a target of action for phenolic acids as shown in the studies described in Tables $\mathbf{1}$ and $\mathbf{2}$.

In vitro studies (Table 1) using adipocytes and macrophages have revealed some of the mechanisms of action of phenolic compounds and their derivatives, which may explain the results observed in in vivo studies, such as the inhibition of adipocyte proliferation, the inhibition of enzymes involved in carbohydrate metabolism and lipid pathways, the attenuation of inflammation and the consequent improvement of adipocyte metabolism [74-77].

In vivo studies (Table 2) have revealed a reduction in inflammatory markers and oxidative stress, a decrease in body weight and improvements in carbohydrate and lipid metabolism by phenolic acid activity [78-85]. For example, hydroxycinnamic acids and their derivatives may regulate adiponectin secretion by inhibiting NF-kB and leukotriene formation [78], but they may also have anti-oxidant and antiglycation properties [86]. Ferulic acid and its derivative, gamma-oryzanol, reduced the risk of high-fat diet-induced hyperglycemia via regulation of insulin secretion and hepatic glucose-regulating enzyme activities [81]. A recent review has shown that ferulic acid derivatives may mediate antiinflammatory effects by down-regulating the proinflammatory transcription factor NF- $\mathrm{BB}$, which in turn can reduce the expression of inflammatory enzymes, such as COX-2 and iNOS, and pro-inflammatory cytokines, such as IL-1 $\beta$, IL- 6 and TNF- $\alpha$. Moreover, these bioactive compounds could up-regulate blood adiponectin levels via indirect activation of PPAR- $\gamma$ through NF-кB inhibition [87].

In summary, the primary beneficial effects attributed to phenolic acids are due to their anti-oxidant activity, regulation of adiponectin secretion, suppression of inflammatory responses, inhibition of the cell cycle and induction of adipocyte apoptosis. However, most studies have been performed in vitro or in animals. Human intervention studies are needed to investigate physiological effects and doseresponse, as well the synergistic action between several types of phenolic acids on metabolic alterations related to human obesity. It seems that derivatives of phenolic acids in the form of esters have greater pharmacological potential in adipose tissue $[87,88]$, and this must be further investigated.

\section{n-3 Long-chain Polyunsaturated Fatty Acids}

Eicosapentaenoic acid (EPA) and docosahexaenoic acid (DHA) (Fig. 2i) are polyunsaturated fatty acids (n-3) that have been highly investigated because of their functional properties in adipose tissue.

In vitro studies (Table 3 ) have shown that both fatty acids inhibit adipocyte differentiation, increase cell apoptosis, and up-regulate the expression of PPAR- $\gamma$, as well as proteins that enhance glucose uptake and improve insulin resistance [89-92]. Moreover, EPA has been shown to decrease the TNF- $\alpha$-induced activation of lipolysis and NF-kB and ERK1/2 signalling pathways in 3T3-L1 adipocytes [93]. The beneficial metabolic effects of DHA and EPA have also been related to their ability to promote AMPK activation and to regulate adipokine secretion [94-96].

In vivo studies (Table 4) have demonstrated that EPA improves insulin resistance and hypolipidemia in animals fed a high-fat diet, reduces adipose tissue inflammation and visceral adiposity, increases adipocyte apoptosis and serum adiponectin, and up-regulates mitochondrial biogenesis, which may induce $\beta$-oxidation in white fat [97-101]. The reduction in retroperitoneal adipose tissue has aroused great interest since an increase in fat deposits in this area is highly associated with metabolic abnormalities related to obesity.

At concentrations commonly consumed in the diet, EPA and DHA have shown little effect on body composition in animals $[102,103]$. However, the supplementation of fatty acids at a higher dosage, when associated with diets restrictive in energy, seems to potentiate weight loss [104, 105].

Despite the evidence described above, human trials have not always demonstrate the benefits of EPA and DHA supplementation in the treatment of obesity [106]. The dosage of fatty acid supplementation that could result in bioactivity necessary for obesity treatment is difficult to establish because these compounds are already present in the diet and have been combined in different proportions in each study. Distinct combinations and dietary influence can induce the anti-inflammatory effects of these fatty acids on the body. 
Table 3. In Vitro Studies Showing Effects of n-3 Long-chain Polyunsaturated Fatty Acids and Lipoic Acid in the Modulation of Inflammatory Pathways and Adipogenesis

\begin{tabular}{|c|c|c|c|c|c|}
\hline $\begin{array}{l}\text { Bioactive } \\
\text { Compound }\end{array}$ & Cell Type & Dosage & $\begin{array}{l}\text { Exposure } \\
\text { Time }\end{array}$ & Major Effects & Reference \\
\hline DHA & 3T3-L1 adipocytes & $25-200 \mu \mathrm{M}$ & $10 \mathrm{~d}$ & $\begin{array}{c}\downarrow \text { glycerol-3-phosphate dehydrogenase, } \downarrow \text { cell size and lipid } \\
\text { accumulation of dose-dependent manner and } \uparrow \text { apoptosis } \\
\text { and } \uparrow \text { lipolysis }\end{array}$ & [89] \\
\hline DHA & 3T3-L1 adipocytes & $125 \mu \mathrm{M}$ & $24 \mathrm{~h}$ & $\uparrow$ secretion and mRNA of adiponectin & [90] \\
\hline$E P A$ & 3T3-L1 adipocytes & $200 \mu \mathrm{M}$ & $24 \mathrm{~h}$ & $\uparrow$ secretion and expression of apelin & [91] \\
\hline$E P A$ & Human adipocytes & $100 \mu \mathrm{M}$ & $48 \mathrm{~h}$ & $\uparrow$ adiponectin secretion & [92] \\
\hline$E P A$ & $\begin{array}{l}\text { Primary rat and } 3 \mathrm{~T} 3-\mathrm{L} 1 \\
\text { adipocytes }\end{array}$ & $\begin{array}{l}100 \text { and } \\
200 \mu \mathrm{M}\end{array}$ & 24 and $96 \mathrm{~h}$ & $\begin{array}{l}\downarrow \text { IL-6-induced lipolysis, modulation of anti-inflammatory } \\
\text { mechanisms involving protein phosphorylation }\end{array}$ & {$[93,96]$} \\
\hline$E P A$ & $\begin{array}{l}\text { Primary cultured rat and } \\
\text { 3T3-L1 adipocytes }\end{array}$ & $200 \mu \mathrm{M}$ & 24 and $96 \mathrm{~h}$ & $\begin{array}{l}\text { Modulation (in visceral fat) of gene expression and protein } \\
\text { secretion appointed as involved in insulin resistance }\end{array}$ & [94] \\
\hline $\begin{array}{l}\text { Alpha-lipoic } \\
\quad \text { acid }\end{array}$ & 3T3-L1 adipocytes & $0.1-10 \mu \mathrm{M}$ & $24 \mathrm{~h}$ & $\begin{array}{c}\uparrow \text { mitochondrial mass, } \uparrow \text { expression of mitochondrial DNA, } \\
\uparrow \text { mitochondrial complexes, } \uparrow \text { oxygen consumption and } \uparrow \\
\text { fatty acid oxidation }\end{array}$ & {$[105]$} \\
\hline $\begin{array}{l}\text { Alpha-lipoic } \\
\quad \text { acid }\end{array}$ & 3T3-L1 adipocytes & $\begin{array}{c}100,250 \text { and } 500 \\
\mu \mathrm{M}\end{array}$ & $1,2,3,6 \mathrm{~d}$ & $\begin{array}{l}\text { Modulation of adipocyte differentiation by regulation pro- } \\
\text { adipogenic transcription factors via mitogen-activated } \\
\text { protein kinase pathways. Biphasic mode of LA action on } \\
\text { mRNA levels of the adipogenic transcription factors }\end{array}$ & [108] \\
\hline $\begin{array}{l}\text { Alpha-lipoic } \\
\text { acid }\end{array}$ & 3T3-L1 adipocytes & $250 \mathrm{mM}$ & $1 \mathrm{~h}$ & $\begin{array}{c}\uparrow \text { phosphorylation of Sp1 and inhibition Sp1, transcrip- } \\
\text { tional activity, inhibition of leptin }\end{array}$ & [109] \\
\hline $\begin{array}{l}\text { Alpha-lipoic } \\
\quad \text { acid }\end{array}$ & 3T3-L1 adipocytes & $250 \mu \mathrm{M}$ & $24 \mathrm{~h}$ & $\uparrow$ apelin secretion & [110] \\
\hline $\begin{array}{l}\text { Alpha-lipoic } \\
\text { acid }\end{array}$ & $\mathrm{T}$ cells & 50 and $100 \mu \mathrm{g} / \mathrm{ml}$ & $5 \mathrm{~min}$ & $\begin{array}{c}\downarrow \text { IL-6 levels, } \downarrow \text { IL-17, } \downarrow \text { inflammation via cAMP and pro- } \\
\text { tein kinase A signaling }\end{array}$ & [111] \\
\hline
\end{tabular}

$\downarrow$, decrease; $\uparrow$, increase; DHA, docosahexaenoic acid; EPA, eicosapentaenoic acid; IL, interleukin; LA; alpha-lipoic acid; Sp1, SV40 promoter-1; cAMP, cyclic adenosine monophosphate.

\section{Lipoic Acid}

Lipoic acid (LA, Fig. 2j) is an organo-sulfur compound derived from caprylic acid that acts as a co-factor of mitochondrial enzymes. It is synthesised in the human body, but is also widely distributed in foods and has attracted much interest because of its anti-oxidant effects and therapeutic potential [107].

In vitro studies (Table 3 ) have demonstrated the effect of LA in modulating adipogenesis [108] and the production of adipokines, such as leptin, adiponectin and apelin. These alterations improve mitochondrial function by stimulating organelle biogenesis, increasing fatty acid oxidation and reducing inflammation [109-111].

Animal studies (Table 4) have demonstrated that LA can be beneficial for obesity management through different mechanisms including reduction of inflammation via cAMP and protein kinase A signalling, prevention of high-fat dietinduced weight gain, slight increase in apelin expression, and decrease in intestinal sugar uptake and insulin resistance $[110,112,113]$.

Human trials appear to confirm the beneficial effects of LA in obesity (Table 2). In obese subjects, supplementation with LA resulted in greater reduction in body weight, abdominal circumference, and blood pressure [114, 115]. However, short-term LA supplementation did not prevent the lipid-induced dysregulation of glucose homeostasis in obese and overweight non-diabetic men [116].

These data reinforce the importance of better exploring the therapeutic value of LA in the treatment of obesity. Bimodal action depending on the LA concentration observed in vitro, needs to be investigated in vivo.

\section{DISCUSSION}

As mentioned previously, in regards to obesity the dysfunction of the adipocyte leads to systemic metabolic consequences that are triggered especially through pro-oxidant and pro-inflammatory mechanisms (Fig. 1). The present review confirms that different phenolic compounds and fatty acids share a common anti-oxidant effect in adipose tissue. This conclusion leads one to question the usefulness of oxidative stress reduction in adipose tissue as an approach to obesity management. Data appear to affirm this approach. Oxidative stress is considered one of the mechanisms responsible for the impairment of adipocyte function in obesity. It leads to the modulation of gene expression regulated by redox 
Table 4. In Vivo and Ex-Vivo Studies Showing Effects of n-3 Long-chain Polyunsaturated Fatty Acids and Lipoic Acid in the Modulation of Inflammatory Pathways and Adipogenesis

\begin{tabular}{|c|c|c|c|c|c|}
\hline $\begin{array}{l}\text { Bioactive } \\
\text { Compound }\end{array}$ & Cell Type & Dosage & $\begin{array}{l}\text { Exposure } \\
\text { Time }\end{array}$ & Major Effects & Reference \\
\hline EPA & $\mathrm{C} 57 \mathrm{BL} / 6 \mathrm{~J}$ mice & $\begin{array}{c}36 \mathrm{~g} / \mathrm{kg} \text { of high-fat } \\
\text { diet }\end{array}$ & $11 \mathrm{wk}$ & $\begin{array}{l}\downarrow \text { adipose inflammation and lipogenesis, } \uparrow \text { markers of fatty } \\
\text { acid oxidation, } \downarrow \text { saturated fat-induced insulin resistance }\end{array}$ & [97] \\
\hline EPA and DHA & C57BL/6J mice & $\begin{array}{l}6 \% \text { EPA plus } 51 \% \\
\text { DHA diet }\end{array}$ & $4 \mathrm{wk}$ & $\begin{array}{c}\uparrow \text { genes of mitochondrial proteins, } \uparrow \text { expression of CTP- } 1 \\
\text { gene } \\
\uparrow \text { fatty acid oxidation in epididymal fat }\end{array}$ & [98] \\
\hline EPA & Wistar rats & $1 \mathrm{~g} / \mathrm{kg} / \mathrm{d}$ & $5 \mathrm{wk}$ & $\begin{array}{c}\downarrow \text { weigh body gain, } \downarrow \text { intake food, } \uparrow \text { production of leptin, } \downarrow \\
\text { PPAR } \gamma, \uparrow \text { apoptosis; } \downarrow \text { TNF-a, } \uparrow \text { adiponectin }\end{array}$ & [99] \\
\hline EPA & $\begin{array}{l}\text { Wistar rats: standard and } \\
\text { high-fat diets }\end{array}$ & $1 \mathrm{~g} / \mathrm{kg} / \mathrm{d}$ & $35 \mathrm{~d}$ & $\downarrow$ retroperitoneal fat, $\downarrow$ epididymal fat, $\downarrow$ IL-6 mRNA & {$[100]$} \\
\hline EPA & $\begin{array}{l}\text { Wistar rats: standard and } \\
\text { high-fat diets }\end{array}$ & $1 \mathrm{~g} / \mathrm{kg} / \mathrm{d}$ & $5 \mathrm{wk}$ & $\begin{array}{l}\text { Down-regulation of genes involved in fatty acid synthesis: } \\
\text { acetyl CoA carboxylase in muscle and liver fatty acid syn- } \\
\text { thase }\end{array}$ & [101] \\
\hline $\begin{array}{l}\text { Alpha-lipoic } \\
\text { acid }\end{array}$ & $\begin{array}{l}\text { Wistar rats: standard and } \\
\text { high-fat diets }\end{array}$ & $\begin{array}{l}0.25 \mathrm{~g} \mathrm{LA} / 100 \mathrm{~g} \\
\quad \text { of diet }\end{array}$ & $8 \mathrm{wk}$ & $\begin{array}{c}\uparrow \text { apelin mRNA, } \downarrow \text { intake food, } \downarrow \text { fat mass, prevented obe- } \\
\text { sity }\end{array}$ & [110] \\
\hline $\begin{array}{l}\text { Alpha-lipoic } \\
\text { acid }\end{array}$ & Wistar rats fed high-fat diet & $\begin{array}{l}0.25 \mathrm{~g} \mathrm{LA} / 100 \mathrm{~g} \\
\text { of diet }\end{array}$ & $8 \mathrm{wk}$ & $\begin{array}{l}\text { Prevents body weight gain, reduces intestinal sugar trans- } \\
\text { port }\end{array}$ & [112] \\
\hline $\begin{array}{l}\text { Alpha-lipoic } \\
\text { acid }\end{array}$ & $\begin{array}{l}\text { Wistar rats fed standard and } \\
\text { high-fat diets }\end{array}$ & $\begin{array}{l}0.25 \mathrm{~g} \mathrm{LA} / 100 \mathrm{~g} \\
\quad \text { of diet }\end{array}$ & $8 \mathrm{wk}$ & $\begin{array}{c}\uparrow \text { adiponectin/total WAT ratio, } \uparrow \text { AMPK, negative correla- } \\
\text { tion between HOMA index and serum adiponectin/total } \\
\text { WAT ratio }\end{array}$ & [113] \\
\hline $\begin{array}{l}\text { Alpha-lipoic } \\
\text { acid }\end{array}$ & Human trial & $1200 \mathrm{mg}$ LA & $\begin{array}{l}6 \mathrm{~h} \text { after } \\
\text { intake }\end{array}$ & $\begin{array}{l}\text { Anti-inflammatory effects of LA are mediated in part by the } \\
\text { cAMP/PKA signaling cascade }\end{array}$ & [114] \\
\hline $\begin{array}{l}\text { Alpha-lipoic } \\
\text { acid }\end{array}$ & $\begin{array}{l}\text { Human trial: } 1127 \text { obese, } \\
\text { and pre-obese individuals }\end{array}$ & $800 \mathrm{mg} / \mathrm{d}$ & $120 \mathrm{~d}$ & $\begin{array}{l}\text { Higher reduction of body weight, abdominal circumference } \\
\text { and blood pressure }\end{array}$ & [115] \\
\hline $\begin{array}{l}\text { Alpha-lipoic } \\
\text { acid }\end{array}$ & $\begin{array}{l}\text { Human trial: } 360 \text { obese } \\
\text { individuals }\end{array}$ & $\begin{array}{c}1200 \text { or } 1800 \\
\mathrm{mg} / \mathrm{d}\end{array}$ & $20 \mathrm{wk}$ & Significantly greater weight loss for $1800 \mathrm{mg} / \mathrm{d}$ & [116] \\
\hline
\end{tabular}

$\downarrow$, decrease; $\uparrow$, increase; C; EPA, eicosapentaenoic acid; DHA, docosahexaenoic acid; CTP-1, mitochondrial citrate transport protein; PPAR- $\gamma$, peroxisome proliferator-activated receptors- $\gamma$; TNF- $\alpha$, tumour necrosis factor- $\alpha$; IL- interleukin; WAT, white adipose tissue; HOMA; homeostasis model assessment; LA, lipoic acid; cAMP, cyclic adenosine monophosphate.

mechanisms, especially those involved in inflammation and insulin signalling [117]. In fact, in obesity, the production of ROS is increased in adipose tissue [9] and enzymatic antioxidant mechanisms are inhibited [118].

Although the expression of several proteins can be modulated by NBCs, the effect of prolonged exposure on the profile of expressed genes remains unknown. Doubts remain as to whether the down- and up-regulatory mechanisms are permanent or transient; thus, recommendation cannot be made as to the best method of NBC exposure for obesity treatment: chronic or pulse exposures and dosages. All of this needs to be clarified in future studies.

This review (Tables 1, 2, 3 and 4) reveals that in in vitro assays, the exposure time of the adipocytes to the action of bioactive compounds varied between 5 minutes and 10 days. Similarly, in human and animal studies, the period of supplementation ranged from 30 hours to 120 days. Long-term supplementation studies remain unavailable.
Another issue that merits discussion is the concentration of compounds used in these studies. Most NBCs in this review are contained in foods at very low concentrations. Considering the numerous factors that affect their bioavailability in the human body, it is assumed that dietary intake of these NBCs through foods would not result in concentrations at the adipocyte comparable to those used in experimentation. Thus, many in vitro assays may be demonstrative of the pharmacological effects of these bioactive compounds and not the physiologically attainable levels. Moreover, little is known about the serum levels of such bioactive compounds in the general population and the concentrations reached in the target tissues.

All of these considerations suggest that to obtain the effects of these bioactive compounds as observed in the studies reviewed here, supplementation is the most adequate strategy. For example, to increase the bioavailability of NBCs, nanoparticles of proteic or lipidic nature could be used [119]. Consequently, it is recommended that future studies test 
lower concentrations of these bioactive compounds to clarify potential nano-bioactivity in the modulation of gene expression. Another approach is the study of synergistic effects via the combination of these NBCs.

The potential of NBCs to attenuate inflammation, prevent oxidative stress, and improve metabolic activity of the adipocyte is an exciting approach to the treatment of obesity. Several mechanisms of great pathophysiological significance can be modulated by these compounds, especially oxidative stress, inflammation and adipocyte differentiation (Fig. 3).

The collected evidence suggests that the NBCs discussed in this review exhibit the ability to reduce inflammation and improve insulin resistance in adipose tissue through several mechanisms, such as increased lipid oxidation and stimulation of mitochondrial biogenesis in adipose tissue as well as lipotropic effects in the liver. The latter effect should not be neglected, although this aspect is beyond the scope of this work. It is known that the metabolic changes that occur in the liver as a result of obesity are important mechanisms that underlie development of metabolic syndrome and insulin resistance [120].

The traditional and simplistic idea that correction for the imbalance between caloric intake and energy expenditure is adequate treatment for obesity must be revolutionized. There is convincing scientific evidence that adipose tissue metabolism is modulated by NBCs. This modulation results in beneficial systemic effects by minimizing lipotoxicity in other tissues reducing the risk of comorbidities associated with obesity. However, it is noteworthy that the effects of NBCs should only be considered as adjuvants in the treatment of obesity. Gene modulation by NBCs can help to optimise therapy through intervention in the metabolic changes that hinder the success of treatment, support the obese state, and increase the risk of comorbidities. However, the restoration of energy balance by decreasing caloric intake and/or increasing energy expenditure will always be the main objective in obesity treatment, something for which nutritional education remains crucial.

\section{CONCLUSION}

The aforementioned food compounds may act on transcriptional gene regulation, metabolic processes and hormone levels by diverse mechanisms. Their primary activities involve reducing the inflammatory response and oxidative stress, decreasing insulin resistance and stimulating mitochondrial biogenesis and lipolysis. However, information from clinical studies to define the dose-response relationship,

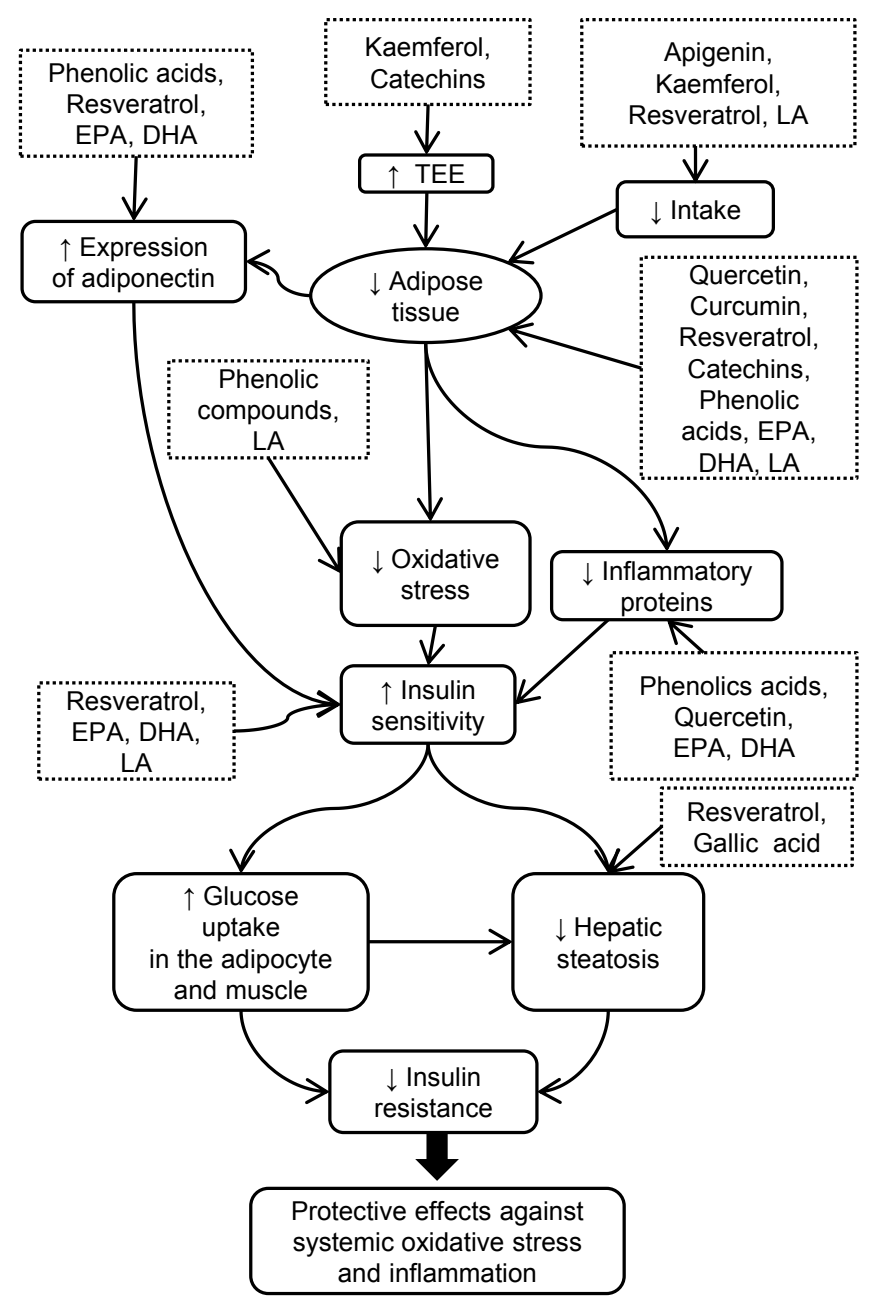

Fig. (3). Targets for action of phenolic compounds, EPA, DHA and lipoic acid to improve pathophysiological conditions in obesity. $\downarrow$, reduction; $\uparrow$, increase; EPA, eicosapentaenoic acid; DHA, docosahexaenoic acid, LA, lipoic acid; TEE, total energy expenditure. 
necessary time of exposure and potential side effects of these NBCs in the treatment of obesity is lacking. In conclusion, despite evidence that phenolic compounds, EPA, DHA, and LA have the potential to modulate the metabolic and secretory functions of adipose tissue, which could lead to clinically significant systemic effects in the management of obesity, clinical studies are required to establish their effective and safe use.

\section{CONFLICT OF INTEREST}

The authors confirm that this article content has no conflicts of interest.

\section{ACKNOWLEDGEMENTS}

This work was supported by Postgraduate Program in Nutrition Science (University Federal of Viçosa-Brazil), and the Ministry of Science and Innovation of the Government of Spain (AGL 2009-10873/ALI) and by Línea Especial: 'Nutrición, Obesidad y Salud' (University of Navarra-Spain). Sônia M. R. Ribeiro was supported by a postdoctoral fellowship from CAPES-Brasília/BRAZIL, partnership BrazilSpain (CAPES-DGU). FAPEMIG Foundation Research (Fundação de Amparo à Pesquisa do Estado de Minas Gerais, Brasil), by financial support (fee publication).

\section{REFERENCES}

[1] Kelly T, Yang W, Chen CS, Reynolds K, He J. Global burden of obesity in 2005 and projections to 2030. Int J Obes 2008; 32: 14317.

[2] Ford ES, Giles WH, Dietz WH. Prevalence of the Metabolic Syndrome Among US Adults. JAMA 2002; 287: 356-9.

[3] Kirk SFL, Penney TL, McHugh TL, Sharma AM. Effective weight management practice: a review of the lifestyle intervention evidence. Int J Obes 2012; 36: 178-85.

[4] Bastard JP, Maachi M, Lagathu C et al. Recent advances in the relationship between obesity, inflammation, and insulin resistance. Eur Cytokine Netw 2006; 17: 4-12.

[5] Yamauchi T, Waki H, Terauchi Y et al. The fat-derived hormone adiponectin reverses insulin resistance associated with both lipoatrophy and obesity. Nat Med 2001; 7: 941-6.

[6] Lê K-A, Mahurkar S, Alderete TL et al. Subcutaneous Adipose Tissue Macrophage Infiltration Is Associated With Hepatic and Visceral Fat Deposition, Hyperinsulinemia, and Stimulation of NFкB Stress Pathway. Diabetes 2011; 60: 2802-9.

[7] Semple RK, Chatterjee VK, S SOR. PPAR gamma and human metabolic disease. J Clin Invest 2006; 116: 581-9.

[8] Berger JP. Role of PPAR $\gamma$, transcriptional cofactors, and adiponectin in the regulation of nutrient metabolism, adipogenesis and insulin action: view from the chair. Int J Obes (Lond) 2005; 29: 3-4.

[9] Furukawa S, Fujita T, Shimabukuro $\mathrm{M}$ et al. Increased oxidative stress in obesity and its impact on metabolic syndrome. J Clin Invest 2004; 114: 1752-61.

[10] Pan M-H, Lai C-S, Dushenkov S, Ho C-T. Modulation of Inflammatory Genes by Natural Dietary Bioactive Compounds. J Agric Food Chem 2009; 57: 4467-77.

[11] Evans DA, Hirsch JB, Dushenkov S. Phenolics, inflammation and nutrigenomics. J Sci Food Agric 2006; 86: 2503-9.

[12] Chen D, Wang CY, Lambert JD, Ai N, Welsh WJ, Yang CS. Inhibition of human liver catechol-O-methyltransferase by tea catechins and their metabolites: Structure-activity relationship and molecular-modeling studies. Biochem Pharmacol 2005; 69: 152331.

[13] Sykiotis GP, Habeos IG, Samuelson AV, Bohmann D. The role of the antioxidant and longevity-promoting $\mathrm{Nrf2}$ pathway in metabolic regulation. Curr Opin Clin Nutr 2011; 14: 41-8.
[14] Funakoshi-Tago M, Nakamura K, Tago K, Mashino T, Kasahara T. Anti-inflammatory activity of structurally related flavonoids, Apigenin, Luteolin and Fisetin. Int Immunopharmacol 2011; 11: 1150-9.

[15] Rahman I, Biswas SK, Kirkham PA. Regulation of inflammation and redox signaling by dietary polyphenols. Biochem Pharmacol 2006; 72: 1439-52.

[16] Hamalainen M, Nieminen R, Vuorela P, Heinonen M, Moilanen E. Anti-inflammatory effects of flavonoids: genistein, kaempferol, quercetin, and daidzein inhibit STAT-1 and NF- $\mathrm{BB}$ activations, whereas flavone, isorhamnetin, naringenin, and pelargonidin inhibit only NF- $\mathrm{KB}$ activation along with their inhibitory effect on iNOS expression and NO production in activated macrophages. Mediators Inflamm 2007; 2007: 1-10.

[17] Crespo L, Garcia-Mediavilla MV, Gutierrez B, Sanchez-Campos S, Tuñón MJ, González-Gallego J. A comparison of the effects of kaempferol and quercetin on cytokine-induced pro-inflammatory status of cultured human endothelial cells. Br J Nutr 2008; 100: 968-76.

[18] Fang XK, Gao J, Zhu DN. Kaempferol and quercetin isolated from Euonymus alatus improve glucose uptake of 3T3-L1 cells without adipogenesis activity. Life Sci 2008; 82: 615-22.

[19] Ding L, Jin D, Chen X. Luteolin enhances insulin sensitivity via activation of PPAR $\gamma$ transcriptional activity in adipocytes. J Nutr Biochem 2010; 21: 941-7.

[20] Chen CY, Peng WH, Tsai KD, Hsu SL. Luteolin suppresses inflammation-associated gene expression by blocking NF-kappaB and AP-1 activation pathway in mouse alveolar macrophages. Life Sci 2007; 81: 1602-14.

[21] Xagorari A, Papapetropoulos A, Mauromatis A, Economou M, Fotsis T, Roussos C. Luteolin Inhibits an Endotoxin-Stimulated Phosphorylation Cascade and Proinflammatory Cytokine Production in Macrophages. J Pharmacol Exp Ther 2001; 296: 1817.

[22] Ono M, Fujimori K. Antiadipogenic Effect of Dietary Apigenin through Activation of AMPK in 3T3-L1 Cells. J Agric Food Chem 2011; 59: 13346-52.

[23] Mahat MYA, Kulkarni NM, Vishwakarma SL, et al. Modulation of the cyclooxygenase pathway via inhibition of nitric oxide production contributes to the anti-inflammatory activity of kaempferol. Eur J Pharmacol 2010; 642: 169-76.

[24] Myoung H-J, Kim G, Nam K-W. Apigenin isolated from the seeds of Perilla frutescens britton var crispa (Benth.) inhibits food intake in C57BL/6J mice. Arch Pharm Res 2010; 33: 1741-6.

[25] da-Silva WS, Harney JW, Kim BW et al. The small polyphenolic molecule kaempferol increases cellular energy expenditure and thyroid hormone activation. Diabetes 2007; 56: 767-76.

[26] Boots AW, Haenen GRMM, Bast A. Health effects of quercetin: From antioxidant to nutraceutical. Eur J Pharmacol 2008; 585: 32537.

[27] Rivera L, Moron R, Sanchez M, Zarzuelo A, Galisteo M. Quercetin Ameliorates Metabolic Syndrome and Improves the Inflammatory Status in Obese Zucker Rats. Obesity 2008; 16: 2081-87.

[28] Loke WM, Proudfoot JM, McKinley AJ et al. Quercetin and its in vivo metabolites inhibit neutrophil-mediated low-density lipoprotein oxidation. J Agric Food Chem 2008; 56: 3609-15.

[29] Bischoff SC. Quercetin: potentials in the prevention and therapy of disease. Curr Opin Clin Nutr Metab Care 2008; 11: 733-40.

[30] Ahn J, Lee H, Kim S, Park J, Ha T. The anti-obesity effect of quercetin is mediated by the AMPK and MAPK signaling pathways. Biochem Biophys Res Commun 2008; 373: 545-49.

[31] Yang J-Y, Della-Fera MA, Rayalam S, et al. Enhanced inhibition of adipogenesis and induction of apoptosis in 3T3-L1 adipocytes with combinations of resveratrol and quercetin. Life Sci 2008; 82: 1032-39.

[32] Overman A, Chuang CC, McIntosh M. Quercetin attenuates inflammation in human macrophages and adipocytes exposed to macrophage-conditioned media. Int J Obes 2011; 35: 1165-72.

[33] Chuang C-C, Martinez K, Xie G, et al. Quercetin is equally or more effective than resveratrol in attenuating tumor necrosis factor$\alpha-$ mediated inflammation and insulin resistance in primary human adipocytes. Am J Clin Nutr 2010; 92: 1511-21.

[34] Stewart LK, Soileau JL, Ribnicky D, et al. Quercetin transiently increases energy expenditure but persistently decreases circulating markers of inflammation in $\mathrm{C} 57 \mathrm{BL} / 6 \mathrm{~J}$ mice fed a high-fat diet. Metabolism 2008; 57: 39-46. 
[35] Wein S, Behm N, Petersen RK, Kristiansen K, Wolffram S. Quercetin enhances adiponectin secretion by a PPAR- $\gamma$ independent mechanism. Eur J Pharmaceut Sci 2010; 41: 16-22.

[36] Pervaiz S, Holme AL. Resveratrol: Its biologic targets and functional activity. Antioxid Redox Signal 2009; 11: 2851-97.

[37] Frombaum M, Le Clanche S, Bonnefont-Rousselot D, Borderie D. Antioxidant effects of resveratrol and other stilbene derivatives on oxidative stress and NO bioavailability: Potential benefits to cardiovascular diseases. Biochimie 2011; 94: 269-76.

[38] Fischer-Posovszky P, Kukulus V, Tews D et al. Resveratrol regulates human adipocyte number and function in a Sirt1dependent manner. Am J Clin Nutr 2010; 92: 5-15.

[39] Picard F, Kurtev M, Chung N, et al. Sirt1 promotes fat mobilization in white adipocytes by repressing PPAR- $\gamma$. Nature 2004; 429: 771-6.

[40] Chen S, Li Z, Li W, Shan Z, Zhu W. Resveratrol inhibits cell differentiation in 3T3-L1 adipocytes via activation of AMPK. Can J Physiol Pharmacol 2011; 89: 793-9.

[41] Vigilanza P, Aquilano K, Baldelli S, Rotilio G, Ciriolo MR. Modulation of intracellular glutathione affects adipogenesis in 3T3L1 cells. J Cell Physiol 2011; 226: 2016-24.

[42] Gonzales AM, Orlando RA. Curcumin and resveratrol inhibit nuclear factor-kappaB-mediated cytokine expression in adipocytes. Nutr Metab (Lond) 2008; 5: 1-13.

[43] Olholm J, Paulsen SK, Cullberg KB, Richelsen B, Pedersen SB. Anti-inflammatory effect of resveratrol on adipokine expression and secretion in human adipose tissue explants. Int J Obes 2010; 34: $1546-53$.

[44] Baur JA, Pearson KJ, Price NL, et al. Resveratrol improves health and survival of mice on a high-calorie diet. Nature 2006; 444: 33742.

[45] Dal-Pan A, Blanc S, Aujard F. Resveratrol suppresses body mass gain in a seasonal non-human primate model of obesity. BMC Physiol 2010; 10: 1-10.

[46] Kim S, Jin Y, Choi Y, Park T. Resveratrol exerts anti-obesity effects via mechanisms involving down-regulation of adipogenic and inflammatory processes in mice. Biochem Pharmacol 2011; 81: 1343-51.

[47] Kim SJ, Lee YH, Han MD, Mar W, Kim WK, Nam KW. Resveratrol, purified from the stem of Vitis coignetiae pulliat, inhibits food intake in C57BL/6J Mice. Arch Pharm Res 2010; 33: 775-80.

[48] Arias N, Macarulla M, Aguirre L, et al. The combination of resveratrol and conjugated linoleic acid is not useful in preventing obesity. J Physiol Biochem 2011; 67: 471-7.

[49] Alberdi G, Rodríguez VM, Miranda J, et al. Changes in white adipose tissue metabolism induced by resveratrol in rats. Nutr Metab (Lond) 2011; 8: 29

[50] Kang W, Hong HJ, Guan J, et al. Resveratrol improves insulin signaling in a tissue-specific manner under insulin-resistant conditions only: in vitro and in vivo experiments in rodents. Metabolism 2012; 61: 424-33.

[51] Timmers S, Konings E, Bilet L, et al. Calorie Restriction-like Effects of 30 Days of Resveratrol Supplementation on Energy Metabolism and Metabolic Profile in Obese Humans. Cell Metab 2011; 14: 612-22.

[52] Tayyem RF, Heath DD, Al-Delaimy WK, Rock CL. Curcumin Content of Turmeric and Curry Powders. Nutr Cancer 2006; 52: 126-31.

[53] Aggarwal BB, Van KME, Iyer LH, Harikumar KB, Sung B. Molecular targets of nutraceuticals derived from dietary spices: potential role in suppression of inflammation and tumorigenesis. Exp Biol Med 2009; 234: 825-49.

[54] Zhao J, Sun X-B, Ye F, Tian W-X. Suppression of fatty acid synthase, differentiation and lipid accumulation in adipocytes by curcumin. Mol Cell Biochem 2011; 351: 19-28.

[55] Kim CY, Le TT, Chen C, Cheng J-X, Kim KH. Curcumin inhibits adipocyte differentiation through modulation of mitotic clonal expansion. J Nutr Biochem 2011; 22: 910-20.

[56] Ejaz A, Wu D, Kwan P, Meydani M. Curcumin Inhibits Adipogenesis in 3T3-L1 Adipocytes and Angiogenesis and Obesity in C57/BL Mice. J Nutr 2009; 139: 919-25.

[57] Tang Y, Zheng S, Chen A. Curcumin eliminates leptin's effects on hepatic stellate cell activation via interrupting leptin signaling. Endocrinology 2009; 150: 3011-20.
[58] Graham A. Curcumin adds spice to the debate: lipid metabolism in liver disease. Br J Pharmacol 2009; 157: 1352-3.

[59] Shehzad A, Ha T, Subhan F, Lee Y. New mechanisms and the antiinflammatory role of curcumin in obesity and obesity-related metabolic diseases. Eur J Nutr 2011; 50: 151-61.

[60] Bravo L. Polyphenols: Chemistry, dietary sources, metabolism, and nutritional significance. Nutr Rev 1998; 56: 317-33.

[61] Kim H, Sakamoto K. (-)-Epigallocatechin gallate suppresses adipocyte differentiation through the MEK/ERK and PI3K/AKT pathways. Cell Biol Int 2011; 36: 147-53.

[62] Ueda M, Furuyashiki T, Yamada K, et al. Tea catechins modulate the glucose transport system in 3T3-L1 adipocytes. Food Funct 2010; 1: 167-73.

[63] Chan CY, Wei L, Castro-Muñozledo F, Koo WL. (-)Epigallocatechin-3-gallate blocks 3T3-L1 adipose conversion by inhibition of cell proliferation and suppression of adipose phenotype expression. Life Sci 2011; 89: 779-85.

[64] Kajimoto O, Kajimoto Y, Yabune M, et al. Tea Catechins with a Galloyl Moiety Reduce Body Weight and Fat. J Health Sci 2005; 51: 161-71.

[65] Nagao $\mathrm{T}$, Komine $\mathrm{Y}$, Soga $\mathrm{S}$, et al. Ingestion of a tea rich in catechins leads to a reduction in body fat and malondialdehydemodified LDL in men. Am J Clin Nutr 2005; 81: 122-9.

[66] Nagao T, Hase T, Tokimitsu I. A green tea extract high in catechins reduces body fat and cardiovascular risks in humans[ast]. Obesity 2007; 15: 1473-83.

[67] Wu C-H, Lu F-H, Chang C-S, Chang T-C, Wang RH, Chang CJ. .Relationship among Habitual Tea Consumption, Percent Body Fat, and Body Fat Distribution. Obesity 2003; 11: 1088-95.

[68] Choo JJ. Green tea reduces body fat accretion caused by high-fat diet in rats through $\beta$-adrenoceptor activation of thermogenesis in brown adipose tissue. J Nutr Biochem 2003; 14: 671-6.

[69] Klaus S, Pultz S, Thone-Reineke C, Wolfram S. Epigallocatechin gallate attenuates diet-induced obesity in mice by decreasing energy absorption and increasing fat oxidation. Int $\mathrm{J}$ Obes Relat Metab Disord 2005; 29: 615-23.

[70] Friedrich M, Petzke KJ, Raederstorff D, Wolfram S, Klaus S. Acute effects of epigallocatechin gallate from green tea on oxidation and tissue incorporation of dietary lipids in mice fed a high-fat diet. Int J Obes 2011;36: 735-43.

[71] Wang H, Wen $\mathrm{Y}, \mathrm{Du} \mathrm{Y}$, et al. Effects of catechin enriched green tea on body composition. Obesity 2010; 18: 773-9.

[72] Basu A, Sanchez K, Leyva MJ, et al. Green tea supplementation affects body weight, lipids, and lipid peroxidation in obese subjects with metabolic syndrome. J Am Coll Nutr 2010; 29: 31-40.

[73] Nagao T, Meguro S, Hase T, et al. A Catechin-rich Beverage Improves Obesity and Blood Glucose Control in Patients With Type 2 Diabetes. Obesity 2008; 17: 310-7.

[74] Hsu C-L, Huang S-L, Yen G-C. Inhibitory Effect of phenolic acids on the proliferation of 3T3-L1 preadipocytes in relation to their antioxidant activity. J Agric Food Chem 2006; 54: 4191-7.

[75] Hsu C-L, Lo W-H, Yen G-C. Gallic acid induces apoptosis in 3t311 pre-adipocytes via a fas- and mitochondrial-mediated pathway. $\mathrm{J}$ Agric Food Chem 2007; 55: 7359-65.

[76] Nagasaka R, Chotimarkorn C, Shafiqul IM, Hori M, Ozaki H, Ushio H. Anti-inflammatory effects of hydroxycinnamic acid derivatives. Biochem Biophys Res Commun 2007; 358: 615-9.

[77] Ohara K, Uchida A, Nagasaka R, Ushio H, Ohshima T. The effects of hydroxycinnamic acid derivatives on adiponectin secretion. Phytomedicine 2009; 16: 130-7.

[78] Ohara K, Kiyotani Y, Uchida A, et al. Oral administration of $\gamma$ aminobutyric acid and $\gamma$-oryzanol prevents stress-induced hypoadiponectinemia. Phytomedicine 2011; 18: 655-60.

[79] Nagasaka R, Yamsaki T, Uchida A, Ohara K, Ushio H. $\gamma$-Oryzanol recovers mouse hypoadiponectinemia induced by animal fat ingestion. Phytomedicine 2011; 18: 669-71.

[80] Hsu C-L, Wu C-H, Huang S-L, Yen G-C. Phenolic compounds rutin and o-coumaric acid ameliorate obesity induced by high-fat diet in rats. J Agric Food Chem 2009; 57: 425-31.

[81] Son MJ, Rico CW, Nam SH, Kang MY. Effect of oryzanol and ferulic acid on the glucose metabolism of mice fed with a high-fat diet. J Food Sci 2011; 76: 7-10.

[82] Cho A-S, Jeon S-M, Kim M-J et al. Chlorogenic acid exhibits antiobesity property and improves lipid metabolism in high-fat dietinduced-obese mice. Food Chem Toxicol 2010; 48: 937-43. 
[83] Hsu C-L, Yen G-C. Effect of gallic acid on high fat diet-induced dyslipidaemia, hepatosteatosis and oxidative stress in rats. Br J Nutr 2007; 98: 727-35.

[84] Hiltunen LA. Are there associations between coffee consumption and glucose tolerance in elderly subjects? Eur J Clin Nutr 2006; 60: 1222-5.

[85] Thom E. The effect of chlorogenic acid enriched coffee on glucose absorption in healthy volunteers and its effect on body mass when used long-term in overweight and obese people. J Int Med Res 2007; 35: 900-8.

[86] Kim J, Jeong I, Kim C, Lee Y, Kim JM, Kim JS Chlorogenic acid inhibits the formation of advanced glycation end products and associated protein cross-linking. Arch Pharm Res 2011; 34: 495500 .

[87] Islam S, Nagasaka R, Ohara K, et al. Biological abilities of rice bran-derived antioxidant phytochemicals for medical therapy. Curr Top Med Chem 2011; 11: 1847-53.

[88] Totani N, Tateishi S, Takimoto T, Maeda Y, Sasaki H. Gallic acid glycerol ester promotes weight-loss in rats. J. Oleo Sci 2011; 60: 457-62.

[89] Kim HK, Della-Fera M, Lin J, Baile CA. Docosahexaenoic acid inhibits adipocyte differentiation and induces apoptosis in 3T3-L1 preadipocytes. J Nutr Biochem 2006; 136: 2965-9.

[90] Oster RT, Tishinsky JM, Yuan Z, Robinson LE. Docosahexaenoic acid increases cellular adiponectin mRNA and secreted adiponectin protein, as well as PPAR $\gamma$ mRNA, in 3T3-L1 adipocytes. Appl Physiol Nutr Metab 2010; 35: 783-9.

[91] Lorente-Cebrián S, Bustos M, Marti A, Martinez JA, MorenoAliaga MJ. Eicosapentaenoic acid up-regulates apelin secretion and gene expression in 3T3-L1 adipocytes. Mol Nutr Food Res 2010; 54: 104-11.

[92] Tishinsky JM, Ma DWL, Robinson LE. Eicosapentaenoic acid and rosiglitazone increase adiponectin in an additive and ppar $\gamma$ dependent manner in human adipocytes. Obesity 2011; 19: 262-8.

[93] Lorente-Cebrián S, Bustos M, Marti A, Fernández-Galilea M, Martinez JA, Moreno-Aliaga MJ. Eicosapentaenoic acid inhibits tumour necrosis factor- $\alpha$-induced lipolysis in murine cultured adipocytes. J Nutr Biochem 2011; 23: 218-27.

[94] Lorente-Cebrián S, Bustos M, A AM, Martinez JA, Moreno-Aliaga MJ. Eicosapentaenoic acid stimulates AMP-activated protein kinase and increases visfatin secretion in cultured murine adipocytes. Clin Sci 2009; 117: 243-9.

[95] Kopecky J, Rossmeisl M, Flachs P, et al. n-3 PUFA: bioavailability and modulation of adipose tissue function. Proc Nutr Soc 2009; 68: 361-9.

[96] Moreno-Aliaga MJ, Lorente-Cebrián S, Martínez JA. Regulation of adipokine secretion by n-3 fatty acids. Proc Nutr Soc 2010; 69: 324-32.

[97] Kalupahana NS, Claycombe K, Newman SJ, et al. Eicosapentaenoic acid prevents and reverses insulin resistance in high-fat dietinduced obese mice via modulation of adipose tissue inflammation. J Nutr 2010; 140: 1915-22.

[98] Flachs P, Horakova O, Brauner P, et al. Polyunsaturated fatty acids of marine origin upregulate mitochondrial biogenesis and induce $\beta$ oxidation in white fat. Diabetologia 2005; 48: 2365-75.

[99] Perez-Matute P, Perez-Echarri N, Martinez JA, Marti A, MorenoAliaga MJ. Eicosapentaenoic acid actions on adiposity and insulin resistance in control and high-fat-fed rats: role of apoptosis, adiponectin and tumor necrosis factor-alpha. Br J Nutr 2007; 97: 389-98.

[100] Pérez-Echarri N, Pérez-Matute $\mathrm{P}$, Marcos-Gómez $\mathrm{B}$, et al. Differential inflammatory status in rats susceptible or resistant to diet-induced obesity: effects of EPA ethyl ester treatment. Eur J Nutr 2008; 47: 380-6.

[101] Pérez-Echarri N, Pérez-Matute P, Marcos-Gómez B, Marti A, Martínez JA, Moreno-Aliaga MJ. Down-regulation in muscle and liver lipogenic genes: EPA ethyl ester treatment in lean and overweight (high-fat-fed) rats. J Nutr Biochem 2009; 20: 705-14.
[102] Gaíva MH, Couto RC, Oyama LM, et al. Polyunsaturated fatty acid-rich diets: effect on adipose tissue metabolism in rats. $\mathrm{Br} \mathbf{J}$ Nutr 2001; 86: 371-7.

[103] Shirouchi B, Nagao K, Inoue N, Ohkubo T, Hibino H, Yanagita T. Effect of dietary omega 3 phosphatidylcholine on obesity-related disorders in obese Otsuka Long-Evans Tokushima fatty rats. J Agric Food Chem 2007; 55: 7170-6.

[104] Kunesová M, Braunerová R, Hlavatý P, et al. The influence of n-3 polyunsaturated fatty acids and very low calorie diet during a shortterm weight reducing regimen on weight loss and serum fatty acid composition in severely obese women. Phys Res 2006; 55 : 63-72.

[105] Thorsdottir I, Tomasson H, Gunnarsdottir I, et al. Randomized trial of weight-loss-diets for young adults varying in fish and fish oil content. Int J Obes Relat Metab Disord 2007; 31: 1560-6.

[106] DeFina LF, Marcoux LG, Devers SM, Cleaver JP, Willis BL. Effects of omega-3 supplementation in combination with diet and exercise on weight loss and body composition. Am J Clin Nutr 2011; 93: 455-62.

[107] Gorąca A, Huk-Kolega H, Piechota A, Kleniewska P, Ciejka E, Skibska B. Lipoic acid - biological activity and therapeutic potential. Pharmacol Rep 2011; 63: 849-58.

[108] Cho K-J, Moon H-E, Moini H, Packer L, Chung AS. Alpha-lipoic acid inhibits adipocyte differentiation by regulating pro-adipogenic transcription factors via mitogen-activated protein kinase pathways. J Biol Chem 2003; 278: 34823-33.

[109] Prieto-Hontoria PL, Pérez-Matute P, Fernández-Galilea M, Martínez JA, Moreno-Aliaga MJ. Lipoic acid inhibits leptin secretion and Sp1 activity in adipocytes. Mol Nutr Food Res 2011; 55: 1059-69.

[110] Fernández-Galilea M, Pérez-Matute P, Prieto-Hontoria P, Martínez J, Moreno-Aliaga MJ. Effects of lipoic acid on apelin in 3T3-L1 adipocytes and in high-fat fed rats. J Physiol Biochem 2011; 67: 479-86.

[111] Salinthone S, Yadav V, Schillace RV, Bourdette DN, Carr DW. Lipoic Acid Attenuates Inflammation via cAMP and Protein Kinase A Signaling. PLoS ONE 2010; 5: 1-10.

[112] Prieto-Hontoria PL, Pérez-Matute P, Fernández-Galilea M, et al. Lipoic acid prevents body weight gain induced by a high fat diet in rats: effects on intestinal sugar transport. J Physiol Biochem 2009; 65: 43-50.

[113] Prieto-Hontoria PL, Pérez-Matute P, Fernández-Galilea M, Martínez JA, Moreno-Aliaga MJ. Effects of lipoic acid on AMPK and adiponectin in adipose tissue of low- and high-fat-fed rats. Eur J Nutr. 2012 [Epub ahead of print].

[114] Koh EH, Lee WJ, Lee SA, et al. Effects of alpha-lipoic acid on body weight in obese subjects. Am J Med 2011; 124: 85-8.

[115] Carbonelli MG, Renzo LD, Bigioni M, Daniele ND, De Lorenzo A, Fusco MA. Alpha-lipoic acid supplementation: a tool for obesity therapy? Curr Pharm Des 2010; 16: 840-6.

[116] Xiao C, Giacca A, Lewis GF. Short-term oral $\alpha$-lipoic acid does not prevent lipid-induced dysregulation of glucose homeostasis in obese and overweight nondiabetic men. Am J Physiol Endocrinol Metab 2011; 301: 736-41.

[117] Matsuzawa-Nagata N, Takamura $\mathrm{T}$, Ando $\mathrm{H}$, et al. Increased oxidative stress precedes the onset of high-fat diet-induced insulin resistance and obesity. Metabolism 2008; 57: 1071-7.

[118] Roberts CK, Barnard RJ, Sindhu RK, Jurczak M, Ehdaie A, Vaziri $\mathrm{ND}$. Oxidative stress and dysregulation of $\mathrm{NAD}(\mathrm{P}) \mathrm{H}$ oxidase and antioxidant enzymes in diet-induced metabolic syndrome. Metabolism 2006; 55: 928-34.

[119] Petkar KC, Chavhan SS, Agatonovik-Kustrin S, Sawant KK. Nanostructured materials in drug and gene delivery: a review of the state of the art. Crit Rev Ther Drug Carr Syst 2011; 28: 101-64.

[120] Vijayakumar RS, Lin Y, Shia KS, et al. Induction of fatty acid oxidation resists weight gain, ameliorates hepatic steatosis and reduces cardiometabolic risk factors. Int J Obes 2011; 36: 999-06. 